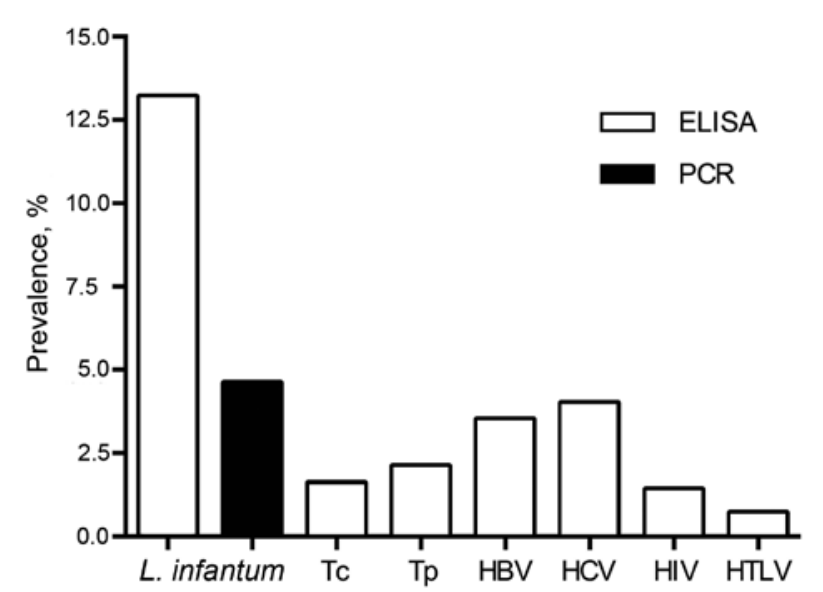

Figure. Comparison of the prevalence of Leishmania infantum as tested by PCR and ELISA and of other infections compulsorily tested in 431 blood donors in Fortaleza, state of Ceará, northeastern Brazil. HBV, hepatitis B virus; $\mathrm{HCV}$, hepatitis $\mathrm{C}$ virus; HTLV, human T-cell lymphotropic virus; Tc, Trypanosoma cruzi; Tp, Treponema pallidum.

determine whether recipients of blood from donors who are PCR positive and/or leishmanial antibody positive become infected with $L$. infantum. Persons with advanced AIDS or other immunosuppressive conditions seemingly would be at greatest risk for VL.

In Brazil, legislation requires that all blood for transfusion be tested for T. cruzi ., hepatitis B and C, T. pallidum, human T-cell lymphotropic virus types 1 and 2, and HIV1 and -2 . As additional information becomes available, screening for $L$. infantum also might be advisable to reduce the possibility of the recipient becoming infected, developing $\mathrm{VL}$, and possibly being a reservoir of infection in the community (10), particularly in Ceará and other regions where the prevalence of $L$. infantum infection is high.

\section{Acknowledgments}

We thank Luciana Carlos for all her help.

This work was supported by CNPq, Brazil (grant 477705/2010-3).

\section{References}

1. Cummins D, Amin S, Halil O, Chiodini PL, Hewitt PE, Radley-Smith R. Visceral leishmaniasis after cardiac surgery. Arch Dis Child. 1995;72:235-6. http://dx.doi.org/10.1136/adc.72.3.235

2. Dey A, Singh S. Transfusion transmitted leishmaniasis: a case report and review of the literature. Indian J Med Microbiol. 2006;24:165-70.

3 Evans TG, Teixeira MJ, McAuliffe IT, Vasconcelos I, Vasconcelos AW, Sousa AQ, et al. Epidemiology of visceral leishmaniasis in northeast Brazil. J Infect Dis. 1992;166:1124-32. http://dx.doi.org/10.1093/infdis/166.5.1124

4. Luz KG, da Silva VO, Gomes EM, Machado FC, Araujo MA, Fonseca HE, et al. Prevalence of anti-Leishmania donovani antibody among Brazilian blood donors and multiply transfused hemodialysis patients. Am J Trop Med Hyg. 1997;57:168-71.

5. Ministry of Health. Brazil. Epidemiological situation. LV—cases [cited 2015 Dec 1]. http://portalsaude.saude.gov.br/index.php/ o-ministerio/principal/leia-mais-o-ministerio/726-secretaria-svs/ vigilancia-de-a-a-z/leishmaniose-visceral-lv/11334-situacaoepidemiologica-dados

6. Evans TG, Krug EC, Wilson ME, Vasconcelos A, Alencar JE, Pearson RD. Evaluation of antibody responses in American visceral leishmaniasis by ELISA and immmunoblot. Mem Inst Oswaldo Cruz. 1989;84:157-66. http://dx.doi.org/10.1590/ S0074-02761989000200003

7. de Oliveira CI, Báfica A, Oliveira F, Favali CB, Correa T, Freitas LA, et al. Clinical utility of polymerase chain reactionbased detection of Leishmania in the diagnosis of American cutaneous leishmaniasis. Clin Infect Dis. 2003;37:e149-53. http://dx.doi.org/10.1086/379610

8. Barral A, Pedral-Sampaio D, Grimaldi Júnior G, Momen H, McMahon-Pratt D, Ribeiro de Jesus A, et al. Leishmaniasis in Bahia, Brazil: evidence that Leishmania amazonensis produces a wide spectrum of clinical disease. Am J Trop Med Hyg. 1991;44:536-46.

9. Fukutani KF, Figueiredo V, Celes FS, Cristal JR, Barral A, Barral-Netto M, et al. Serological survey of Leishmania infection in blood donors in Salvador, northeastern Brazil. BMC Infect Dis. 2014;14:422. http://dx.doi.org/10.1186/1471-2334-14-422

10. Costa CH, Gomes RB, Silva MR, Garcez LM, Ramos PK, Santos RS, et al. Competence of the human host as a reservoir for Leishmania chagasi. J Infect Dis. 2000;182:997-1000. http://dx.doi.org/10.1086/315795

Address for correspondence: Anastácio Q. Sousa, Rua Nestor Barbosa, 315, Parquelândia. CEP 60455-610, Fortaleza, Ceará, Brazil; email: aqsousa@gmail.com; Daniela C.S. Monteiro, Rua Suiça, 196, Pires Façanha. CEP 61760-903, Eusébio, Ceará, Brazil; email: daniela.monts@gmail.com

\title{
Morbillivirus and Pilot Whale Deaths, Canary Islands, Spain, 2015
}

\section{Eva Sierra, Antonio Fernández, Cristian Suárez-Santana, Aina Xuriach, Daniele Zucca, Yara Bernaldo de Quirós, Natalia García-Álvarez, Jesús De la Fuente, Simona Sacchini, Marisa Andrada, Josué Díaz-Delgado, Manuel Arbelo}

Author affiliation: University of Las Palmas de Gran Canaria, Arucas (Las Palmas), Canary Islands, Spain

DOI: http://dx.doi.org/10.3201/eid2204.150954

To the Editor: Four strains of cetacean morbillivirus (CeMV; family Paramyxoviridae, genus Morbillivirus) have been detected in the global cetacean population: porpoise morbillivirus (1), dolphin morbillivirus (2), pilot whale morbillivirus (PWMV) (3), and Longman's beaked whale morbillivirus (4). In addition, 2 novel 
CeMV sequences or strains isolated from the Indo-Pacific bottlenose dolphin (Tursiops aduncus) and the Guiana dolphin (Sotalia guianensis) have been recently reported in the Southern Hemisphere $(5,6)$.

Pilot whales are known to be susceptible to 2 strains of CeMV, PWMV, and dolphin morbillivirus $(3,7,8)$. Only 2 deaths of whales have been reported to be caused by PWMV: 1 long-finned pilot whale (Globicephala melas) (3) and 1 short-finned pilot whale (G. macrorhynchus) (8). We report deaths of 3 short-finned pilot whales caused by PWMV in the northeastern Atlantic Ocean along the coast of the Canary Islands, Spain.

During mid-January-May 2015, a total of 3 whales (animals 1,2, and 3) were found dead along the coasts of the Canary Islands (Table). Complete standardized necropsy was performed for all whales. Tissue samples from animals 1 and 2 were collected and fixed in 10\% neutral-buffered formalin for histologic and immunohistochemical analyses (online Technical Appendix Figure, http://wwwnc.cdc.gov/ EID/article/22/4/15-0954-Techapp1.pdf). Immunohistochemical analysis was performed (brain, intestine, lymph nodes, lung, kidney, adrenal gland, uterus, ovary, testis, and spleen) by using a monoclonal antibody against the nucleoprotein of canine distemper virus (CDV-NP; VMRD, Inc., Pullman, WA, USA) (7). Samples of lung, pulmonary lymph nodes, larynx, laryngeal tonsil, intestine, spleen, and brain were frozen $\left(-80^{\circ} \mathrm{C}\right)$ for virologic analysis.

Grossly, the most remarkable findings in animal 1 were severe suppurative rhinitis, with clogged nasal passages by the accumulation of large quantity of purulent material, otitis media, sacculitis, and laryngitis. Severe diffuse epithelial hyperplasia and hyperkeratosis was observed along the upper respiratory tract and keratinized stomach. Animal 2 had severe proliferative dermatitis and cheilitis, and severe, suppurative, laryngeal tonsillitis. Animal 3 had advanced autolysis, which precluded pathologic analysis.

Histologically, moderate, multifocal, bronchointerstitial pneumonia, severe suppurative tonsillitis and systemic lymphoid depletion were identified in animals 1 and 2. Severe nonsuppurative meningoencephalitis with neuronal and glial cell degeneration and necrosis, microgliosis and syncytial cells were observed in animal 2.

Immunohistochemical analysis showed morbillivirus antigen in the bronchiolar epithelium, type 2 pneumocytes, and alveolar multinucleate cells. Syncytia from lymph nodes, laryngeal tonsil, spleen, and intestine also showed positive immunolabeling for morbillivirus. Epithelial tropism caused by the virus was suggested by identification of viral antigen in epithelia of the lung, larynx, keratinized stomach, intestine, kidney, urinary bladder, epididymis, and endometrial glands. In addition, intense immunolabeling was detected in neurons (soma, dendrites, axon hillock, and axons) and glial cells, primarily throughout the cerebral gray matter of animal 2 .

Molecular detection of CeMV was performed by a using a 1-step reverse transcription PCR for a 426-bp conserved region of the phosphoprotein gene (7). All tested samples from animals 1 and 2 and a laryngeal tonsil sample from animal 3 showed positive PCR results. Because co-infections with herpesvirus and morbillivirus were observed during morbillivirus epizootics in seals in 1988 and dolphins in 2006-2007, we also tested the same tissue for herpesvirus by conventional nested PCR (9). Herpesvirus DNA was detected in all samples from animal 1 except

\begin{tabular}{|c|c|c|c|c|c|c|c|c|}
\hline $\begin{array}{l}\text { Animal no., } \\
\text { age/sex }\end{array}$ & $\begin{array}{l}\text { Total body } \\
\text { length, cm }\end{array}$ & $\begin{array}{l}\text { Weight, } \\
\text { kg }\end{array}$ & $\begin{array}{c}\text { Date } \\
\text { stranded }\end{array}$ & Location & $\begin{array}{c}\text { Decomposition } \\
\text { code }\end{array}$ & $\begin{array}{l}\text { Main pathologic } \\
\text { findings }\end{array}$ & $\begin{array}{l}\text { IHC-positive } \\
\text { result }\end{array}$ & $\begin{array}{c}\text { PCR-positive } \\
\text { result }\end{array}$ \\
\hline $1, \mathrm{~J} / \mathrm{F}$ & 202 & 119 & Jan 14 & Fuerteventura & $\begin{array}{l}\text { Moderate } \\
\text { autolysis }\end{array}$ & $\begin{array}{c}\text { Dermatitis, } \\
\text { suppurative rhinitis, } \\
\text { paranasal sinusitis, } \\
\text { otitis media, air } \\
\text { sacculitis, laryngitis, } \\
\text { laryngeal tonsillitis, } \\
\text { BIP, hyperkeratotic } \\
\text { gastritis, lymphoid } \\
\text { depletion }\end{array}$ & $\begin{array}{l}\text { Lung, larynx, } \\
\text { laryngeal } \\
\text { tonsil, lymph } \\
\text { nodes, spleen, } \\
\text { adrenal gland, } \\
\text { keratinized } \\
\text { stomach, } \\
\text { intestine, } \\
\text { uterus, ovary }\end{array}$ & $\begin{array}{l}\text { Lung, larynx, } \\
\text { pulmonary } \\
\text { lymph node, } \\
\text { laryngeal } \\
\text { tonsil, } \\
\text { spleen, } \\
\text { intestine }\end{array}$ \\
\hline 2, C/M & 168 & 75 & May 15 & Fuerteventura & Fresh & $\begin{array}{l}\text { Dermatitis, cheilitis, } \\
\text { suppurative } \\
\text { laryngeal tonsillitis, } \\
\text { BIP, encephalitis }\end{array}$ & $\begin{array}{c}\text { Lung, } \\
\text { laryngeal } \\
\text { tonsil, lymph } \\
\text { nodes, spleen, } \\
\text { kidney, testis, } \\
\text { epididymis, } \\
\text { intestine, } \\
\text { adrenal gland, } \\
\text { urinary } \\
\text { bladder, brain }\end{array}$ & $\begin{array}{l}\text { Lung, } \\
\text { pulmonary } \\
\text { lymph node, } \\
\text { laryngeal } \\
\text { tonsil, } \\
\text { intestine, } \\
\text { brain }\end{array}$ \\
\hline $3, \mathrm{~A} / \mathrm{M}$ & 448 & 900 & May 20 & Tenerife & $\begin{array}{l}\text { Advanced } \\
\text { autolysis }\end{array}$ & Advanced autolysis & None & $\begin{array}{l}\text { Laryngeal } \\
\text { tonsil }\end{array}$ \\
\hline
\end{tabular}


lung, although no specific lesions compatible with this infectious agent were observed.

A pool containing all morbillivirus-positive PCR amplicons for animals 1 and 2 (GenBank accession nos. KT006289 and KT006290), a PCR amplicon for the brain sample from animal 2 (GenBank accession no. KT006291), and a PCR amplicon for the larynx from animal 3 were sequenced. A BLAST search (http://www.ncbi.nlm.nih.gov/ blast/Blast.cgi) showed that amplified samples were nearly identical to reference PWMV sequences (GenBank accession nos. AF200817 [3] and FJ842381 [8]). The sequence obtained from animal 3 was too short and degenerated to be accurately classified as CeMV, although it showed high homology with PWMV and porpoise morbillivirus.

It has been proposed that pilot whales might be enzootically infected with CeMV (10). These whales might be responsible for maintaining and transmitting CeMV over long distances or to other odontocetes. No die-offs have been observed in these species. However, an outbreak of a lethal morbillivirus infection in long-finned pilot whales caused by a dolphin morbillivirus strain occurred in the Mediterranean Sea during the end of October 2006-April 2007 (7).

Results of this study support the previous hypothesis that pilot whales have a species-adapted morbillivirus but indicate that lethal infections are not as rare as previously believed (3). The tropism of the virus in these cases, the high number of multinucleated syncytial cells, and the severity of the lesions resemble the acute systemic symptoms observed in dolphins infected with morbillivirus (2). Thus, pilot whales in the northeastern Atlantic Ocean could be at risk for infection, especially in one of the main pilot whale-watching regions between La Gomera and Southern Tenerife Islands in the Canary Islands, which has $>700,000$ visitors each year.

\section{Acknowledgments}

We thank other members of the Canary Islands Cetacean Stranding Network (Society for the Study of Cetaceans in the Canary Islands and Canary Islands Conservation) for participating in this study.

This study was supported by National Project CGL2012-39681 (Subprograma BOS); Regional Project SolSub C200801000288 and ProID 20100091; Technical Assistant Contract by Canary Islands Government delegation (TEC0002955); and precompetitive project ULPGC2013-21.

\section{References}

1. Barrett T, Visser IK, Mamaev L, Goatley L, van Bressem MF, Osterhaust AD. Dolphin and porpoise morbilliviruses are genetically distinct from phocine distemper virus. Virology. 1993;193:1010-2. http://dx.doi.org/10.1006/viro.1993.1217

2. Domingo M, Visa J, Pumarola M, Marco AJ, Ferrer L, Rabanal R, et al. Pathologic and immunocytochemical studies of morbillivirus infection in striped dolphins (Stenella coeruleoalba). Vet Pathol. 1992;29:1-10. http://dx.doi.org/10.1177/030098589202900101
3. Taubenberger JK, Tsai MM, Atkin TJ, Fanning TG, Krafft AE, Moeller RB, et al. Molecular genetic evidence of a novel morbillivirus in a long-finned pilot whale (Globicephalus melas). Emerg Infect Dis. 2000;6:42-5. http://dx.doi.org/10.3201/ eid0601.000107

4. West KL, Sanchez S, Rotstein D, Robertson KM, Dennison S, Levine G, et al. A Longman's beaked whale (Indopacetus pacificus) strands in Maui, Hawaii, with first case of morbillivirus in the central Pacific. Marine Mammal Science. 2013;29:767-76.

5. Groch KR, Colosio AC, Marcondes MC, Zucca D, Diaz-Delgado J, Niemeyer C, et al. Novel cetacean morbillivirus in Guiana dolphin, Brazil. Emerg Infect Dis. 2014;20:511-3. http://dx.doi.org/10.3201/ eid2003.131557

6. Stephens N, Duignan PJ, Wang J, Bingham J, Finn H, Bejder L 1st, et al. Cetacean morbillivirus in coastal IndoPacific bottlenose dolphins, Western Australia. Emerg Infect Dis. 2014;20:666-70. http://dx.doi.org/10.3201/eid2004.131714

7. Fernández A, Esperon F, Herraez P, de Los Monteros AE, Clavel C, Bernabe A, et al. Morbillivirus and pilot whale deaths, Mediterranean Sea. Emerg Infect Dis. 2008;14:792-4. http://dx.doi.org/10.3201/eid1405.070948

8. Bellière EN, Esperon F, Fernandez A, Arbelo M, Munoz MJ, Sanchez-Vizcaino JM. Phylogenetic analysis of a new Cetacean morbillivirus from a short-finned pilot whale stranded in the Canary Islands. Res Vet Sci. 2011;90:324-8. http://dx.doi.org/10.1016/ j.rvsc. 2010.05 .038

9. VanDevanter DR, Warrener P, Bennett L, Schultz ER, Coulter S, Garber RL, et al. Detection and analysis of diverse herpesviral species by consensus primer PCR. J Clin Microbiol. 1996;34:1666-71.

10. Duignan PJ, House C, Geraci JR, Early G, Copland HG, Walsh MT, et al. Morbillivirus infection in two species of pilot whales (Globicephala sp.) from the western Atlantic. Marine Mammal Science. 1995;11:150-62. http://dx.doi.org/ 10.1111/ j.1748-7692.1995.tb00514.x

Address for correspondence: Eva Sierra, Institute for Animal Health, Veterinary School, University of Las Palmas de Gran Canaria, Arucas (Las Palmas), Canary Islands, Spain; email: esierra@becarios.ulpgc.es

\section{Serogroup-specific Seasonality of Verotoxigenic Escherichia coli, Ireland}

\section{Patricia Garvey, Anne Carroll, Eleanor McNamara, André Charlett, Kostas Danis, Paul J. McKeown}

Author affiliations: European Centre for Disease Prevention and Control (ECDC) European Programme for Intervention Epidemiology Training, Stockholm, Sweden (P. Garvey, K. Danis); Health Service Executive-Health Protection Surveillance Centre, Dublin, Ireland (P. Garvey, P.J. McKeown); ECDC Public Health Microbiology Training Programme, Stockholm (A. Carroll); Health Service Executive Public Health Laboratory-Dublin Mid-Leinster, Dublin (A. Carroll, E. McNamara); Public Health England, London, UK (A. Charlett); Institut de Veille Sanitaire, Paris, France (K. Danis)

DOI: http://dx.doi.org/10.3201/eid2204.151160 